University of Michigan Law School

University of Michigan Law School Scholarship Repository

\title{
Bringing Third Parties into Actions at Law-Set-Off Against the Assignor
}

\author{
Edson R. Sunderland \\ University of Michigan Law School
}

Available at: https://repository.law.umich.edu/articles/1108

Follow this and additional works at: https://repository.law.umich.edu/articles

Part of the Civil Procedure Commons, Common Law Commons, and the Litigation Commons

\section{Recommended Citation}

Sunderland, Edson R. "Bringing Third Parties into Actions at Law-Set-Off Against the Assignor." Mich. L. Rev. 19 (1921): 540-3.

This Response or Comment is brought to you for free and open access by the Faculty Scholarship at University of Michigan Law School Scholarship Repository. It has been accepted for inclusion in Articles by an authorized administrator of University of Michigan Law School Scholarship Repository. For more information, please contact mlaw.repository@umich.edu. 
- Bringing Thmo Parties imo- Actrons ar Law-Sat-off against the Assignor.-It frequently happens, in an action by an assignee, that.the defendant wishes to use as a cross-action a claim against the assignor. This results in no difficulty unless the amount of the set-of against the xssignor is greater. than the claim of the plaintiff, or unless the cross-action calls for a specific remedy against the assigner in addition to its defensive effect upon the plaintiff's demand. In each of these cases we have a three-sided controversy. In the first, the set-off operates against the plaintiff to the extent of his claim and against the assignor for the balance." In the second; the crossaction operates against the plaintiff and his assignor in ways. which may be quite variously different: If the assignor can he brought into the controversy, it can be wholly determined in a single action; otherwise two or more actions are necessary.

In State ex rel. Aläka Pacific Navigation Co. v. Superior Court (Wash, 1920), I94 Pac. 412, there was an-example of the first of these two cases: The plaintiff was assignee of an account solely for collection and claimed no beneficial interest in it. The defendant had 2 cross-demand against the assignor arising out of the same contract. which produced the account sued upon, and this cross-demand exceeded the amount of the plaintif's claim. It pas obvious that the defendant could not get 2 judginent for 2 balance in his favor against the plaintiff, but that this could.be obtained, if at all, only against the assignor. Under 2 familiar statute providing that where a complete determination of the controversy cannot be had without the presence of other parties, the court shall cause them to be brought in, the detendant asked that the action be stayed until the assignor. should be brought in. Refusal to make this order was aftirmed on appeal, the court holding that this, statute referred to necessary parties in the technical sense of that term, and in an action at law, where the defendant makes use of a legal counter-. claim, no third party can be recessary.

The point of interest in this decision is not so much whether it is right on authority as whether it can be justified on broad principles of procedural policy. - It brings up several interesting questions affecting the nature of actions and the relation of parties thereto, and illustrates the extreme antipathy with which professional, conservatism meets proposals for even the most nátural and simple.changes in judicial administration.

1. We have here a three-sided legal controversy. The common law 
was in theory wedded to the idea of 2 iwio-sided controversy $2 s$ the essential condition for judicial action. One plaintiff or 2 unified group of joint plaintifis must sue 2 single defendant or 2 unified group of joint defendants. This principle lies at the foundation of the whole scheme of parties in common law actions. In the case of two plaintiffs, if their interests are several they cannot bring a single action to enforce their rights, thus developing a three-sided controversy, but each must bring 2 separate two-sided action. Gould on PLEADrive, Ch. IV, Sec. 53. In case of two defendants, if their liability is several, each must be 2 sole defendant in $2 \cdot$ separate two-sided. action, and both cannot be joined in 2 three-sided controversy. .30 Crc 120 - If this doctrine of unity of parties is based on the idea of preserving singleness in the issue, the effort is - vain ${ }_{2}$ because by the use of numerous counts and pleas-many issues may arise in a single action. If it is based on the supposed impossibility of splitting up a judgment so as to determine a controversy with more than two sides, it may be answered that the common law did in fact tolerate judgments which determined legal relations among. three or more parties. In Seymour v. Richardson Fueling Co. (1903), 205 III. 77 , the court quotes many common:law authorities in support of the proposition that while the general rule is that the judgment.must be 2 unit. as to all. the defendants in assumpsit, yet "if one defendant pleads matter which goes to his personal discharge, such as bankruptcy, or to his personal disability to contract, such as infancy, or any other matter which does not go to the nature of the writ," judgment may be rendered for such defendant and against the rest. So, where two or more are charged with 2 joint tort. one may be found grilty and another acquitted, as the evidence may require 1 Chitrty on Pleadise, *74 And even in the case of joint plaintiffs, where they are united through 2 comnon interest, one may obtain a judgment in his favor while another fails. Is Stand. ENcyc. of Procteduse, 81. In an these cases the judgment does in fact determine a controversy with three or more sides.

It must be concluded, therefore, that three-sided contropersies have forced themselves within the jurisdiction of common law courts, and that the fact that in the principal case the preserice cf. the- 2ssignor would complicate the issues and call for 2 judgment settling 2 triangular controversy. is no justification in principle for the decision.

2. In the principal case the third party sought to be brought in was not involved in the original-action, but in a cross-action. In" so far as this cross-action operated 25 a defense, thus corresponding to the common law recoupment, it was fully available to the defendant without the presence of 2 third party. But if it was to be used at its full value, resulting in a judgment for the. balance in defendant's favor, the assignor had to be before the court.

Now, in such case, in order to prevent obvious injustice, the usual rales of common law procedure:cannot be permitted to operate. One of two things must be done. Either the third party must be allowed to come into the case, and the liability apportioned between the assignee and assignor, which is contrary to orthodox practice; or the defendant must be authorized 
to split his cause of action and use part of it to extinguish the plaintiff demand and the balance as a. separate claim against the assignor, to be asserted in a separate suit, which is also contrary to the orthodox rule, which probibits splitting a cause of action. From the standpoint of convenience it is clear that bringing in the third party, when it can be done, is the better method. The common law, however, with its technical distrust of simplicity, chose the other method. Confronted by a dilemma which inevitably called for the sacrifice of traditional conventions in one direction or the other, the singie action with three parties was passed by in favor of two separate actions each with two parties, on the two portions of the split demand. Hewnell. v. Fairlamb (1800), 3 Esp. 104; I Coepus Jrers, IIII.

The principal case is therefore in harmony with the common law solution, but no teason exists in principle why.courts should not. in the exercise of common law powers, allow either solution 25 the occasion requires. The courts were forced, in this situation, to do something on their own authority, without statutory aid, and they assumed jurisdiction. If they had power to adopt one plan, there was equal power to adopt the other. Why should ali subsequent courts continue to follow the accidental lead of that riginal choice of a remedial alternative?

3. The usual American counterclaim statute does not expressly authorize a cross-demand which involves new parties, is commonly construed to carrs no implied authority to plead such a demand, and often forbids it in terms. Sunderland, Cases on Code Pleading, 356-364; Taylor v. Matteson (1893), 86. Wis. 113. A very few have provided expressly for bringing in new parties. Kansas St., 1909, Secs. 3602 , s694. The most striking development in this field has been the new Crivi. Pricrice Act adopted in New York in 1920, Sec 271, which contains the following provision:

"Where a defendant sets up any counterchaim which raises questions between .himself and the plaintiff along with any. other persona, he shall set forth the names of all persons who, if such counterclaim were to be enforced by cross-action, would be defendants in such crossaction. When any such person is not a party to the action he shall be summoned to appear by' being served with $a$ copy of the answer. A person not a party to the action who is so served with an answer becomes 2 defendant in the action as if he had been served with the summons.".

Under the English practice it has long been customary to bring in third parties on counterclaims-ORDFr 2A, rule 12; and several British provinces have similar rules. Nova Scotia, Jud. ACr, 192n, Sec. 18(3), and Orusa 2I, rule It; Ontario, Jub. Acr, Rule 113. The principal case is a good illustration of. the utility of such a provision, which would, in this instance, have allowed the whole controversy to be settled i.: a single action. The English practice provides 2 safegtuard against the inconvenient use of the privilege of bringing in third parties; by permitting the third party, when summoned, to show cause why the claim should be proseclited by a separate.suit, and the judge may make such order as may be just. ORDER 2t, sule 15 . 
4. The effort made in the principal case on the part of the defendunt to secure an order bringing in the assignor under the gexeral statute anthorizing new parties who are necessa:y to a complete determination of the controversy, was doomed to failure under the commonly accepted interpretation of that statute. It has been held to apply only to extuitable causes of action or cross-demands. Chapman v. Forbes (1890), $123 \mathrm{~N}$. Y: 538 . In the priocipal case the court distinguished State ex rel. Adjustment Co. v. Superior Court, 67 Wash. 355, " on the gromnd that there the counterclaim was not a mere money demand aaginst the assignee, but an equitable defense callirs for affirmative relief. Another case where the assignor was brought in on a counterclaim pleaded against the assignee is GiLierslecve r. Burrows (18j3). 24 Ohio St. 204, where the counterclaim was an equitable set-off. To be sure, the statute contains no express restriction to equitable actions and cros:demands, but the inevitable tendency to limit the scope of procedural innovations has fixed this implied restriction.

5. The whole question of third partics coming into actions at law has received a broad and generous stimulus in England and seme of the British dominions through rules authorizing so-called Third Party Procedures whereby any defendant entitled to contribution or indemnity over aginin any othet person not 2 party to the action may by leave of court birine such party in, and thereby have the whole controversy, inclyding the indencms or contribution, settled in a single action. England, ORDEx 16, rule \& The practice is widely employed and has demonstrated its great utility.

6. It is apparent that the principal case, while rightly decided under the current authorities, exhibits the very low state of procedural development from which we suffer in this "country, and suggests the reed of both 2 more progressive attitude on the part of our courts and a more.erilightened legisjative policy.

E. R. $S$. 